\title{
Coronavirus Disease 2019 (COVID-19) in a Patient with Disseminated Histoplasmosis and HIV-A Case Report from Argentina and Literature Review
}

\author{
Fernando A. Messina ${ }^{1}$, Emmanuel Marin ${ }^{1}{ }^{(0)}$, Diego H. Caceres $\left.{ }^{2,3}{ }^{(}\right)$, Mercedes Romero ${ }^{1}$, \\ Roxana Depardo ${ }^{1}$, Maria M. Priarone ${ }^{4}$, Laura Rey ${ }^{5}$, Mariana Vázquez ${ }^{6}$, Paul E. Verweij ${ }^{3}$ (i), \\ Tom M. Chiller ${ }^{2}$ and Gabriela Santiso ${ }^{1, *(D)}$ \\ 1 Unidad de Micología, Hospital de Infecciosas F. J. Muñiz B.A. Uspallata 2272, C1282 CABA, Argentina; \\ fmessina35@gmail.com (F.A.M.); emamarin@hotmail.com (E.M.); mecharomero@gmail.com (M.R.); \\ roxanadepardo@yahoo.com.ar (R.D.) \\ 2 Mycotic Diseases Branch, Centers for Disease Control and Prevention (CDC), Atlanta, GA 30333, USA; \\ diegocaceres84@gmail.com (D.H.C.); tnc3@cdc.gov (T.M.C.) \\ 3 Department of Medical Microbiology, Radboud University Medical Center and Center of Expertise in \\ Mycology Radboudumc/CWZ, 9101 Nijmegen, The Netherlands; Paul.Verweij@radboudumc.nl \\ 4 División de HIV SIDA, Hospital de Infecciosas F. J. Muñiz B.A., Uspallata 2272, C1282 CABA, Argentina; \\ maiapriarone@yahoo.com \\ 5 División de Neumonología, Hospital de Infecciosas F. J. Muñiz B.A., Uspallata 2272, C1282 CABA, \\ Argentina; lauradianarey@gmail.com \\ 6 Bacteriología de Guardia, Hospital de Infecciosas F. J. Muñiz B.A., Uspallata 2272, C1282 CABA, Argentina; \\ mariana.belenvazquez@gmail.com \\ * Correspondence: gsantiso@buenosaires.gob.ar
}

Received: 1 October 2020; Accepted: 5 November 2020; Published: 10 November 2020

check for updates

\begin{abstract}
The disease caused by the new SARS-CoV-2, known as Coronavirus disease 2019 (COVID-19), was first identified in China in December 2019 and rapidly spread around the world. Coinfections with fungal pathogens in patients with COVID-19 add challenges to patient care. We conducted a literature review on fungal coinfections in patients with COVID-19. We describe a report of a patient with disseminated histoplasmosis who was likely infected with SARS-CoV-2 and experienced COVID-19 during hospital care in Buenos Aires, Argentina. This patient presented with advanced HIV disease, a well-known factor for disseminated histoplasmosis; on the other hand, we suspected that COVID-19 was acquired during hospitalization but there is not enough evidence to support this hypothesis. Clinical correlation and the use of specific Histoplasma and COVID-19 rapid diagnostics assays were key to the timely diagnosis of both infections, permitting appropriate treatment and patient care.
\end{abstract}

Keywords: Histoplasmosis; Histoplasma; COVID-19; Coronavirus

\section{Introduction}

Coronaviruses are positive-sense RNA viruses and are named for the crown-like spikes on their surface. There are hundreds of coronaviruses, which usually infect animals, birds and various mammals, like camelids, bats, civets, rats, mice, cats and dogs [1]. The first report of human coronavirus disease was in the mid-1960s. Since this first report, there have been seven coronaviruses reported to infect humans and four of these usually cause mild to moderate symptoms of the upper respiratory tract, such as the common cold. In the past two decades, the other three coronaviruses have been recognized as causing serious disease in humans, leading to two large outbreaks and the current global pandemic [1-3]. 
The first known large outbreak of coronavirus disease occurred in 2002 in the Guangdong province, China. This outbreak of Severe Acute Respiratory Syndrome (SARS) spread to five continents, affecting 8098 people and causing a total of 774 deaths [4]. A second large outbreak of coronavirus occurred in 2012 and emerged on the Arabian Peninsula and was given the name Middle East Respiratory Syndrome (MERS-CoV). MERS-CoV cases were reported in 27 countries. Since 2012, the World Health Organization (WHO) has reported a total of 2494 infections and 858 deaths [5,6]. In December 2019, a novel coronavirus (SARS-CoV-2), which is the causative agent of coronavirus disease 2019 (COVID-19), was identified in Wuhan, China. The WHO declared this a global pandemic on 11 March $2020[7,8]$. As of the end of October 2020, the COVID-19 pandemic has spread to 216 countries, areas or territories, has affected more than 45 million people and has caused more than a million deaths worldwide [8]. In Argentina, the first case of COVID-19 was identified on 3 March 2020 and by 31 October 2020 the Argentinean Ministry of Health reported more than one million cases and 30,000 deaths [9].

Histoplasmosis, a disease caused by the dimorphic thermal fungus Histoplasma capsulatum, is frequently reported in the Americas but recently is increasingly reported in regions outside the "traditional" endemic region [10-12]. Histoplasmosis presents with a wide range of clinical manifestations, from flu-like symptoms to multiple manifestations of disseminated histoplasmosis (DH). DH principally affects individuals with immunodeficiencies, especially people living with HIV (PLHIV) with advanced disease [13].

\section{Case Report and Results}

In early June 2020, a 36-year-old female with HIV was admitted at the emergency service after experiencing 15 days of dyspnea, cough and night sweats. HIV was diagnosed ten years prior and the patient was not adherent to HIV antiretroviral therapy (ART). The last ART treatment was in June 2018 (atazanavir/ritonavir, tenofovir/emtricitabine). The patient was a heavy smoker, more than 30 cigarettes/day since she was 14 years old and also a person who uses drugs (marijuana and cocaine). Over the two months prior to hospital admission she had developed asthenia and adynamia. On admission (day 1) the patient had fever (temperature $38.2^{\circ} \mathrm{C}$ ), a respiratory rate of 20 breaths per minute, oxygen saturation of $95 \%$, a heart rate of 106 beats per minute and a blood pressure of 110/80 mm Hg. She presented with hypoventilation and skin and mucosal lesions, including papule-like lesions near her right malar and nose area and an erythematous lesion slightly ulcerated in the central palate. The patient also presented with a bilateral and diffuse micronodular interstitial pattern on the chest computed tomography (CT, Figure 1). Laboratory analysis showed a low white blood cell count $\left(3200\right.$ cells $\left./ \mathrm{mm}^{3}\right)$ and low hemoglobin and hematocrit $(10.1 \mathrm{~g} / \mathrm{dL}$ and $31 \%$ respectively) and a normal platelet count $\left(191,000\right.$ cells $\left./ \mathrm{mm}^{3}\right)$. Serum biochemistry analysis was normal. Her HIV viral load was 356,000 copies $/ \mathrm{mm}^{3}$ and a CD4 cell count of 3 cells $/ \mathrm{mm}^{3}$ (Figure 2).
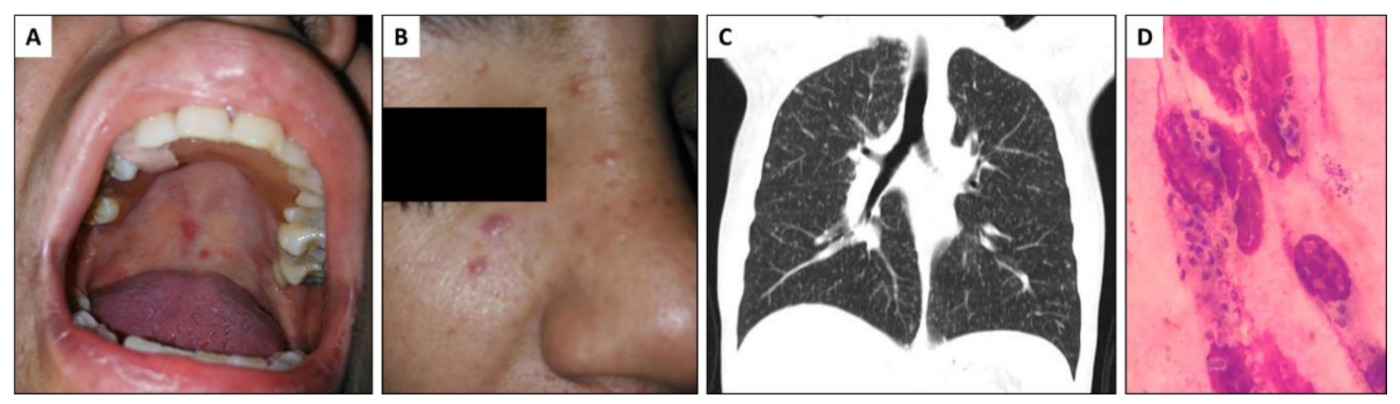

Figure 1. Clinical findings: (A,B) Papule-like lesions in the right malar region and in the proximal area of the nose and erythematous lesion with slight central ulceration in the central palate. (C) Chest computed tomography (CT), without contrast, revealed a bilateral and diffuse micronodular interstitial pattern, compatible with miliary histoplasmosis. (D) Wright-Giemsa stain on sputum smear, intracellular clusters of budding yeast compatible with H. capsulatum using Wright-Giemsa stain. 


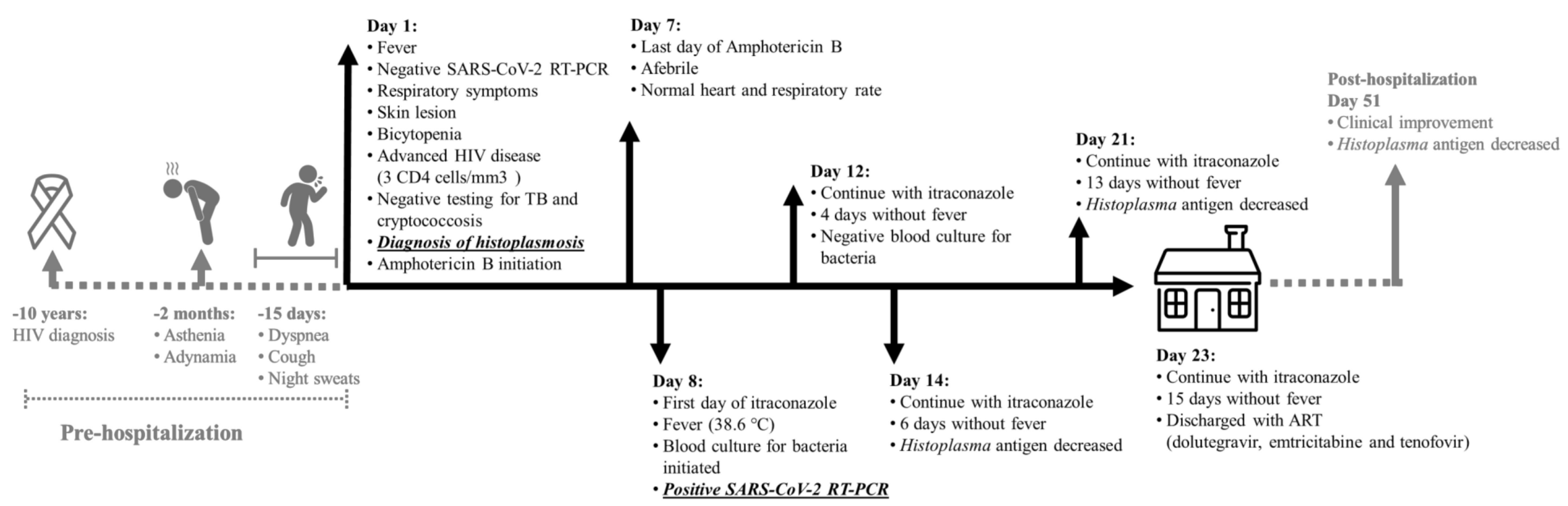

Figure 2. Case timeline: Coronavirus disease 2019 (COVID-19) in a patient with progressive disseminated histoplasmosis from Argentina. 
On admission at the emergency department and due the low CD4 cells count, samples for tuberculosis (TB) and mycology analysis were collected, including sputum, blood cultures (processed by lysis centrifugation), sera and urine. Specimens were tested for Histoplasma and Cryptococcus antigen detection (Clarus Histoplasma GM enzyme immunoassay and $\mathrm{CrAg}{ }^{\circledR}$ LFA cryptococcal antigen, both products from IMMY, Norman, OK, USA) and immunodiffusion method for detection of Histoplasma specific antibodies. Sputum smear microscopy was negative for acid-fast bacilli (AFB) using Ziehl-Neelsen (ZN) stain but intracellular clusters of budding yeast compatible with $H$. capsulatum were observed using Wright-Giemsa stain (Figure 1). Results of antigen testing came back within $24 \mathrm{~h}$. Cryptococcus antigen was negative and Histoplasma antigen was positive, with a concentration of $24.7 \mathrm{ng} / \mathrm{mL}$ in urine and $5.10 \mathrm{ng} / \mathrm{mL}$ in serum (Figures 2 and 3). Based on these laboratory findings, the diagnosis of histoplasmosis was established and the patient started treatment with deoxycholate amphotericin B $(\mathrm{dAmB})$ in a dose of $0.7 \mathrm{mg} / \mathrm{kg}$ per day [14]. Following institutional protocols, a nasopharyngeal swab sample was collected and tested for SARS-CoV-2 by Real-time polymerase chain reaction (RT-PCR), which was negative and the patient had no history of contact with a person with suspected or confirmed COVID-19 (Figure 2).

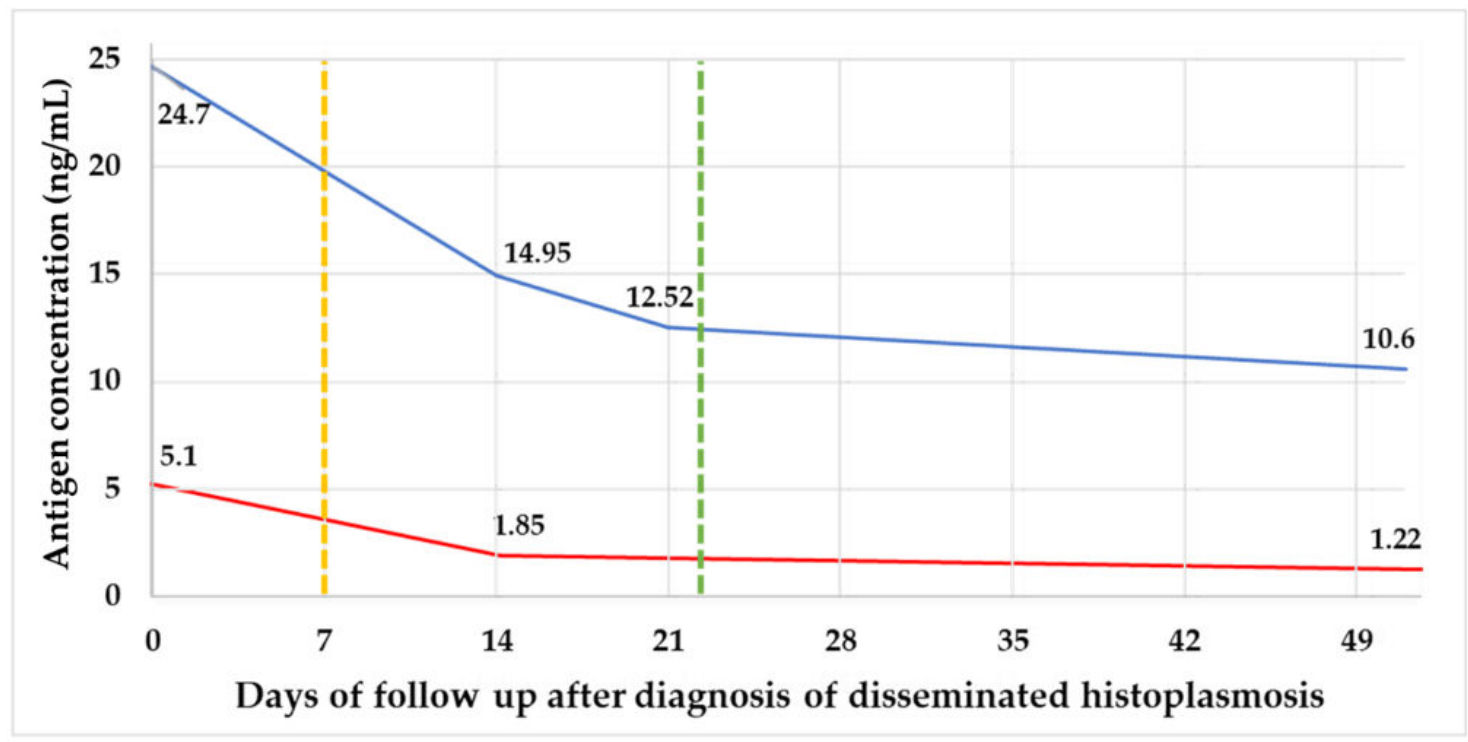

- Antigen in urine — Antigen in sera -- Day of COVID-19 diagnosis - - Hospital discharge

Figure 3. Follow-up using Histoplasma antigen testing in a patient with disseminated histoplasmosis and COVID-19.

After three days of $\mathrm{dAmB}$ (day 3 of admission), patient became afebrile, with normal heart and respiratory rate and oxygen saturation of $95 \%$. Immunodiffusion testing was non-reactive for Histoplasma antibodies. Renal function parameters showed normal blood levels of creatinine, sodium and potassium and slightly elevated blood urea nitrogen. After 7 days of $\mathrm{dAmB}$ therapy, mucosal lesions disappeared and the skin lesions improved and antifungal therapy was switched to itraconazole capsule (200 $\mathrm{mg}$ twice daily), as is indicated on the international histoplasmosis guidelines [14]. On the same day, the patient developed a new fever $\left(38.6^{\circ} \mathrm{C}\right)$, without alteration of respiratory rate and oxygen saturation of $97 \%$ and without other symptoms. A diagnostic workup was performed including blood cultures and a second nasopharyngeal swab sample for SARS-CoV-2 testing. The SARS-CoV-2 RT-PCR test was positive and the patient was moved to a COVID-19 ward. Potential risk factors for severe COVID-19 were not identified in this patient and the disease presented with mild symptoms, so only monitoring of symptoms was done on this patient (Figure 2).

On day 12 , the patient had been afebrile for four days prior, with normal heart and respiratory rate and oxygen saturation of $97 \%$. Blood cultures remained negative. On day 14 , the patient continued to 
be afebrile and follow-up Histoplasma antigen testing in urine and serum showed decreasing antigen levels (Figures 2 and 3). Further decrease of Histoplasma antigen was noted on day 21, indicating a good response to antifungal therapy (Figure 3) and skin lesions disappear. On day 23, which was 15 days without fever and presenting resolution of symptoms, the patient was discharged with itraconazole capsule $400 \mathrm{mg} /$ day and started ART, following the Hospital de Infecciosas F. J. Muñiz's protocol for ART initiation, with dolutegravir, emtricitabine and tenofovir. Twenty-seven days after hospital discharge (day 51), the patient attended a follow-up consultation. Physical evaluation showed further clinical improvement of the patient's medical condition and Histoplasma antigen testing in urine and sera showed a further decrease of antigen levels $(10.6 \mathrm{ng} / \mathrm{mL}$ and $1.22 \mathrm{ng} / \mathrm{mL}$, respectively).

\section{Fungal Infections and COVID-19: Literature Review}

A literature search on PubMed Central was done on 31 July 2020. We searched for the following terms-COVID-19; Coronavirus, SARS-CoV-2, fungal infections, mycoses, histoplasmosis, Histoplasma, aspergillosis, Aspergillus, candidiasis, Candida, Pneumocystis, coccidioidomycosis and Coccidioides and included studies published in English, Spanish and Portuguese. We also did a forward and backward "snowballing" reference chain search. We searched for case reports of cohorts of patients with COVID-19 with co-infection with fungal diseases.

We identified a total of 28 references describing COVID-19 cases co-infected with fungal diseases, including 16 case series and 12 case reports [15-42]. These reports came from 15 countries; half were from European countries (54\%), followed by reports from Asia (28\%), the Americas (14\%) and Oceania (4\%); no reports from Africa were identified. By diagnosis, 17 (61\%) reports described infections by molds, 16 caused by Aspergillus species and one caused by Fusarium proliferatum, three reports described infections caused by yeasts (Candida species and Saccharomyces cerevisiae), two reports of Pneumocystis pneumonia and one report of coccidioidomycosis. Five reports described fungal infections in a hospital series of COVID-19 cases, mostly including infections caused by Aspergillus and Candida species but also cases of mucormycosis and cryptococcosis (Table 1). COVID-19 associated pulmonary aspergillosis (CAPA) was described in 21 of the 28 references reviewed [15-30,38-42]. In summary, a total of 164 cases of CAPA were described, most were caused by A. fumigatus and a few by other Aspergillus species (A. flavus and A. penicillioides). CAPA case series reported prevalence ranging from $8 \%$ to $39 \%$ and mortality rates ranging from $44 \%$ to $67 \%$. All CAPA cases were reported in severe COVID-19 patients (Table 1). Only one report described a SARS-CoV-2 infection in a PLHIV, who developed Pneumocystis pneumonia, based on chest $\mathrm{CT}$ and elevated lactate dehydrogenase (Table 1) [36]. Only one report described a co-infection with a dimorphic fungus, Coccidioides. This was a report of a patient who did not adhere to chronic coccidioidomycosis treatment, who developed moderate COVID-19, no hospitalization was needed in this case [37].

Table 1. Results of the literature review on fungal diseases and COVID-19.

\begin{tabular}{ccc}
\hline Ref & Country & Report Summary \\
\hline Molds (Aspergillus/Fusarium)
\end{tabular}


Table 1. Cont.

\begin{tabular}{|c|c|c|}
\hline Ref & Country & Report Summary \\
\hline \multicolumn{3}{|r|}{ Molds (Aspergillus/Fusarium) } \\
\hline [20] & Belgium * & $\begin{array}{l}\text { Seven CAPA cases on } 20 \text { COVID- } 19 \text { patients on mechanical ventilation ( } 35 \% \text { prevalence). Dx+\%: } \\
\qquad 86 \% \text { culture, } 100 \% \text { GM in BAL, } 0 \% \text { GM in serum. } 57 \% \text { mortality. }\end{array}$ \\
\hline [21] & Netherlands * & $\begin{array}{l}\text { Six CAPA cases on } 31 \text { severe COVID-19 patients (19\% prevalence). Dx+\%: } 83 \% \text { culture, } 50 \% \text { GM } \\
\text { in BAL, } 0 \% \text { GM in serum. } 67 \% \text { mortality. }\end{array}$ \\
\hline [22] & Germany * & $\begin{array}{l}\text { Five CAPA cases on } 19 \text { patients with severe COVID-19 (26\% prevalence). Dx+\%: } 80 \% \text { fungal } \\
\text { PCR, } 60 \% \text { GM in BAL, } 60 \% \text { culture, } 40 \% \text { GM in serum. } 60 \% \text { mortality. }\end{array}$ \\
\hline [23] & France $\Phi$ & $\begin{array}{c}\text { Case report on a critically ill COVID-19 patient. Diagnosis was done by positive PCR on TA; } \\
\text { GM was also positive in serum and TA. BG was negative. A. fumigatus (identified by } \\
\text { MALDI-TOF) was isolated on second TA. Patient died. }\end{array}$ \\
\hline [24] & France ${ }^{\phi}$ & $\begin{array}{l}\text { Description of the first five cases of COVID-19 in France. One CAPA patient, A. flavus isolated } \\
\text { from TA culture. Patient initially was treated with voriconazole and then switched to } \\
\text { isavuconazole. Patient also have co-infected with A. baumannii. Patient died. }\end{array}$ \\
\hline [25] & Italy $\phi$ & $\begin{array}{l}\text { Case report of IPA. Patient diagnosed by positive culture on BAL (A. fumigatus) and positive } \\
\text { serum GM (index: 8.6). Post-mortem lung examination confirmed IPA. }\end{array}$ \\
\hline [26] & Netherlands ${ }^{\Phi}$ & $\begin{array}{l}\text { CAPA report of an azole-resistant Aspergillus fumigatus isolated from TA. TA was also GM } \\
\text { positive ( }>3.0 \text { index). In serum, BG was positive }(1590 \mathrm{pg} / \mathrm{mL}) \text { and GM negative. Patient died. } \\
\text { IPA in a critically ill COVID-19 patient. A. fumigatus isolated from TA and positive antigen using }\end{array}$ \\
\hline [27] & Austria $\Phi$ & $\begin{array}{c}\text { Aspergillus Ag LFA. Serum GM and BG were negative. Patient died after three days of } \\
\text { antifungal treatment. }\end{array}$ \\
\hline [28] & Argentina $\Phi$ & $\begin{array}{l}\text { Case report of ventilator-associated pneumonia involving A. flavus. Patient diagnosed by } \\
\text { culture and positive serum GM. Multiple co-infections (E. faecalis, A. baumanii, } \\
\text { coagulase-negative staphylococci and C. lusitaniae). Patient died. }\end{array}$ \\
\hline [29] & Brazil $^{\phi}$ & $\begin{array}{l}\text { Case report of postmortem IPA caused by Aspergillus penicillioides. Diagnosis was done by } \\
\text { histopathological analysis of lung tissue and PCR with sequencing (ITS1 and ITS2 gen targets). } \\
\text { COVID-19 associated pulmonary aspergillosis caused by A. fumigatus isolated from }\end{array}$ \\
\hline [30] & Australia ${ }^{\phi}$ & $\begin{array}{c}\text { non-bronchoscopy endotracheal aspirate. Patient also presented positive blood culture for } \\
\text { Facklamia hominis and urine culture for Escherichia coli. Patient survived. }\end{array}$ \\
\hline [31] & France $\Phi$ & $\begin{array}{l}\text { ICU patient with acute respiratory failure. After seven days intubated, a mold grew } \\
(7 \times 102 / \mathrm{CFU}) \text { on BAL (no bacteria were detected). MALDI-TOF identified mold as } \\
\text { Fusarium proliferatum. Patient got positive GM (index: } 1.7) \text {. After } 30 \text { days patient was extubated } \\
\text { and translated to a post-ICU area. }\end{array}$ \\
\hline \multicolumn{3}{|r|}{ Yeast (Candida/Saccharomyces) } \\
\hline [32] & Iran * & $\begin{array}{l}53(5 \%) \text { out of } 1059 \text { patients with confirmed COVID-19 infection had OPC. C. albicans was the } \\
\text { most isolated species (71\%), followed by C. glabrata (11\%), C. dubliniensis ( } 9 \%) \text {, C. parapsilosis } \\
(5 \%) \text {, C. tropicalis (3\%) and Pichia kudriavzevii ( } 2 \%) \text {. Most isolates were susceptible to all three } \\
\text { classes of antifungal drugs. }\end{array}$ \\
\hline [33] & India * & $\begin{array}{l}\text { Fifteen }(2.5 \%) \text { BSI among } 596 \text { ICU patients. C. auris caused } 10(67 \%) \text { BSI, followed by C. albicans } \\
(n=3), \text { C. tropicalis }(n=1) \text { and C. krusei }(n=1) \text {. Eight of } 15(53 \%) \text { BSI cases died. Six of } 10(60 \%) \\
\text { of patients with C. auris deceased. }\end{array}$ \\
\hline [34] & Greece * & $\begin{array}{l}\text { Two ICU patients with bloodstream infection caused by Saccharomyces. Cases were linked with } \\
\text { diarrhea treatment using Ultra-Levure (preparation of S. cerevisiae). Patients survived. }\end{array}$ \\
\hline \multicolumn{3}{|r|}{ Opportunistic (Pneumocystis) } \\
\hline [35] & Germany ${ }^{\Phi}$ & 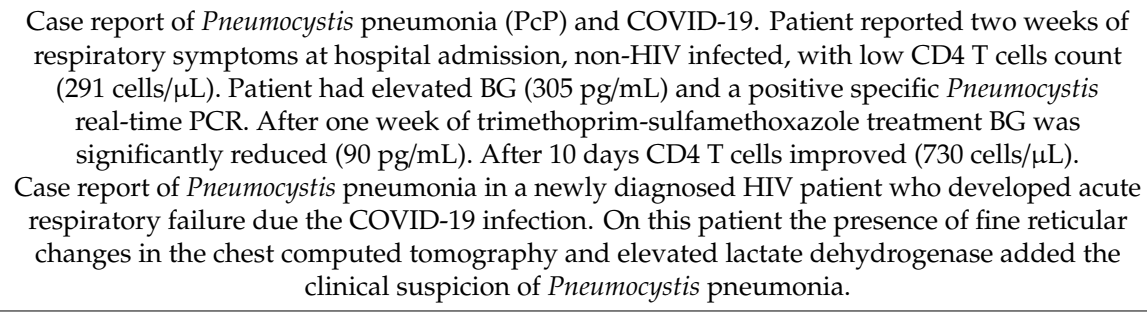 \\
\hline \multicolumn{3}{|r|}{ Dimorphic (Coccidioides) } \\
\hline [37] & USA ${ }^{\phi}$ & $\begin{array}{l}\text { Case report of a chronic cavitary pulmonary coccidioidomycosis nonadherent to therapy and } \\
\text { medical controls. Patient attended primary provider after having } 6 \text { days of fever, cough and } \\
\text { body aches. First was diagnosed with bronchitis and the provider prescribed azithromycin. } \\
\text { Two days later patient went to the emergency for weakness, progressive cough, fever and body } \\
\text { aches. Laboratory testing confirmed COVID-19; patient also presented elevated specific } \\
\text { Coccidioides Ab. Hospitalization was not required. }\end{array}$ \\
\hline
\end{tabular}


Table 1. Cont.

\begin{tabular}{|c|c|c|}
\hline Ref & Country & Report Summary \\
\hline [38] & $\mathrm{UK}^{*}$ & $\begin{array}{l}836 \text { patients with COVID-19 (February to April 2020). Candida spp. and other yeast were } \\
\text { isolated from respiratory samples on } 24(21 \%) \text { of } 112 \text { patients tested. Three patients developed } \\
\text { C. albicans fungemia (all central line-associated infections). Three patients with } A \text {. fumigatus } \\
\text { culture were identified; one patient was classified as colonized, the other two were classified as } \\
\text { possible infection (both were negative GM and BG in serum). }\end{array}$ \\
\hline [40] & China * & $\begin{array}{l}99 \text { COVID-19 cases (January 2020). Four }(4 \%) \text { patients were diagnosed with fungal co-infections } \\
\text { (aspergillosis and candidiasis). } 15(15 \%) \text { patients were under antifungal treatment. }\end{array}$ \\
\hline [41] & China * & $\begin{array}{l}52 \text { COVID-19 critically ill patients. In two patients, } A \text {. flavus and } A \text {. fumigatus were isolated from } \\
\text { respiratory tract secretions (found in one patient each). In one patient C. albicans was isolated } \\
\text { from urine. }\end{array}$ \\
\hline
\end{tabular}

Abbreviations: (Ref) Reference; $\left({ }^{*}\right)$ case series; $\left({ }^{\Phi}\right)$ case report; (CAPA) COVID-19 associated pulmonary aspergillosis; $(\mathrm{Dx}+\%)$ Diagnostics positivity rate: (GM) Galactomannan; (BAL) Bronchoalveolar lavage; (PCR) Polymerase chain reaction; (AspICU) Clinical algorithm to diagnose invasive pulmonary aspergillosis in critically ill patients; (PIPA) Putative invasive pulmonary aspergillosis; (IPA) Invasive pulmonary aspergillosis; (OPC) Oropharyngeal candidiasis; (BSI) bloodstream infections; (BG) $(1 \rightarrow 3)-\beta-D-G l u c a n ;(T A)$ Tracheal aspirate; (Ag) antigen; (LFA) Lateral flow assay; (UK) United Kingdom; (USA) United States of America.

\section{Discussion}

COVID-19 associated with fungal diseases has been reported. These reports mostly describe cases of CAPA and to a much lesser extent other fungal pathogens [15-32,34-42]. The majority of cases are opportunistic secondary infections to COVID-19. We report a case of endemic mycosis in a patient who was likely infected with SARS-CoV-2 while in the hospital. The treatment of histoplasmosis was successful despite the patient having a very poor immune status due to advanced HIV disease and SARS-CoV-2 infection. This case highlights that the diagnosis of fungal infections is even more challenging during the current COVID-19 pandemic, where strategies focusing on containing the pandemic, have significantly reduced access to non-COVID-19-related health care services [43-45]. In addition, medical procedures such as bronchoscopy and bronchoalveolar lavage (BAL) are restricted due to generation of aerosols. These procedures are critical to diagnose other or secondary pulmonary infections, including invasive fungal diseases [43-48].

Among other causes of morbidity and mortality in patients with COVID-19, the frequency and impact of fungal co-infections is still limited, although the number of clinical cases and reports are increasing. It is important to note that mortality reported across these studies is concerning. It is still premature to link these fungal co-infections as significant causes of deaths but it should be noted that the risk factors related to mechanical ventilation, prolonged use of corticosteroids and lung damage caused by COVID-19 together with the cytokine storm could set up these patients for invasive fungal diseases [38,39,43,49-51]. Different than the typical invasive fungal infections (IFI) where COVID-19 may be a host risk factor, this reported case presented with disseminated histoplasmosis and then experienced COVID-19; this secondary viral infection did not affect histoplasmosis treatment and clinical evolution. Strict adherence to hospital mitigation strategies is needed to help reduce risk for SARS-CoV-2 transmission to hospitalized patients at higher risk for severe COVID-19. The immunological profile in patients with COVID-19 has been extensively described. Well known are the systemic inflammatory response, exacerbation of serum inflammatory bio-markers, such as C-reactive protein (CRP), lactic dehydrogenase (LDH), ferritin, D-dimer and IL-2R, IL-6, IL-10, TNF-alpha [52,53]. For PLHIV with COVID-19, information about disease severity and patient outcomes is contradictory and several reports have shown that the mortality and severity of COVID-19 in PLHIV were not increased while other studies report worse evolution in patients with both infections. It is important to mention that most of these studies have reported several methodological limitations, especially the non-evaluation 
of residual confounders [54-58]. In PLHIV it is important to consider the presence of pulmonary fungal coinfections, especially due to the similarity in chest tomographic patterns. In the literature review, we identified a report of Pneumocystis pneumonia (PjP) in a patient newly diagnosed with advanced HIV disease and with severe COVID-19. As important findings on this report, the patient presented reticular changes on the chest radiology with alteration of lactate dehydrogenase, a biomarker usually altered with PjP. These findings added the clinical suspicion of PjP and addressing additional laboratory testing for the confirmation of this coinfection [36]. But, it is also important to mention that similar situations have been reported in persons who are not living with HIV [35,37].

Based on laboratory and epidemiological evidence, we hypothesize that SARS-CoV-2 infection in the patient that we describe in this report happened during hospitalization. But it is important to note that the sensitivity of SARS-CoV-2 RT-PCR in nasopharyngeal swab samples was reported around $70 \%$ and it is therefore unknown whether the first negative result was not a false-negative result [59-62]. There is high risk of COVID-19 spread in hospital, so CDC is constantly updating COVID-19 infection control recommendation. Current recommendations for strengthening standard hospital infection control practices are aimed to reduce nosocomial spread of COVID-19 and protect health care workers [63]. In this case it is particularly important to highlight the role of rapid and accurate diagnostic assays in diagnosis and care of histoplasmosis and COVID-19. Additionally, in this case, Histoplasma antigen testing was crucial in several aspects: (1) Analysis of urine and serum samples represent lower risk of COVID-19 exposure of medical staff to COVID-19; (2) these types of samples are less invasive than other types of samples traditionally used to diagnose histoplasmosis, like BAL or bone marrow aspirate; (3) antigen test was useful for evaluation of the response of the Histoplasma specific antifungal treatment. All these findings correlate with the published guidelines for histoplasmosis diagnosis and treatment in PLHIV [14,64].

\section{Conclusions}

Here we describe a case of disseminated histoplasmosis and COVID-19 in a person with advanced HIV disease. It is well known that advanced HIV is one of the main risks factors for the development of disseminated histoplasmosis. In this patient we suspected that SARS-CoV-2 infection happened during hospitalization but based on information available, it is not possible to proof this hypothesis. Based on this experience, we summarized the main findings of this case and additional evidence published in the literature, aimed to inform other clinicians about fungal co-infection on patients with COVID-19. We highlight the importance of patient's epidemiological and clinical evaluation, supported by rapid and highly accurate diagnostic assays.

Author Contributions: Conceptualization: F.A.M., E.M., D.H.C. and G.S.; Investigation: F.A.M., E.M., D.H.C., M.R., R.D., M.M.P., L.R., M.V., P.E.V., T.M.C. and G.S.; Writing-original draft preparation: F.A.M., E.M., D.H.C., P.E.V., T.M.C. and G.S.; Writing—review and editing: F.A.M., E.M., D.H.C., M.R., R.D., M.M.P., L.R., M.V., P.E.V., T.M.C. and G.S. All authors have read and agreed to the published version of the manuscript.

Funding: This work was partially funded by Oak Ridge Institute for Science and Education (ORISE) as part of a research fellowship for Diego H. Caceres.

Acknowledgments: We want to thank Mark Mezzullo for editing the manuscript.

Conflicts of Interest: The authors declare no conflict of interest. The findings and the conclusions in this report are those of the authors and do not necessarily represent the official position of the Centers for Disease Control and Prevention.

\section{References}

1. CDC. Human Coronavirus Types. Available online: https://www.cdc.gov/coronavirus/types.html (accessed on 15 February 2020).

2. Mahony, J.B.; Zhang, C. Coronavirus Including Severe Acute Respiratory Syndrome (SARS). In Manual of Molecular and Clinical Laboratory Immunology, 7th ed.; ASM Press: Washington, DC, USA, 2006; pp. 803-809. [CrossRef] 
3. Kimberlin, D.W.; Brady, M.T.; Jackson, M.A.; Long, S.S. (Eds.) Coronaviruses, Including SARS and MERS. In Red Book: 2018 Report of the Committee on Infectious Diseases; American Academy of Pediatrics: Washington, DC, USA, 2018; pp. 297-301.

4. WHO. Severe Acute Respiratory Syndrome (SARS). Available online: https://www.who.int/health-topics/ severe-acute-respiratory-syndrome\#tab=tab_1 (accessed on 9 November 2020).

5. CDC. Middle East Respiratory Syndrome (MERS). Available online: https://www.cdc.gov/coronavirus/mers/ index.html (accessed on 2 August 2019).

6. The WHO MERS-CoV Research Group; Abdallat, M.M. State of Knowledge and Data Gaps of Middle East Respiratory Syndrome Coronavirus (MERS-CoV) in Humans. PLoS Curr. 2013, 5, 1-30. [CrossRef]

7. CDC. Coronavirus (COVID-19). Available online: https://www.cdc.gov/coronavirus/2019-ncov/index.html (accessed on 27 October 2020).

8. WHO. Coronavirus Disease (COVID-19) Pandemic. Available online: https://www.who.int/emergencies/ diseases/novel-coronavirus-2019 (accessed on 9 November 2020).

9. Argentina MdS. Reporte Diario Vespertino Situación de COVID-19 En Argentina. Available online: https: //www.argentina.gob.ar/salud/coronavirus-COVID-19 (accessed on 9 November 2020).

10. Bahr, N.C.; Antinori, S.; Wheat, L.J.; Sarosi, G.A. Histoplasmosis Infections Worldwide: Thinking Outside of the Ohio River Valley. Curr. Trop. Med. Rep. 2015, 2, 70-80. [CrossRef]

11. Adenis, A.A.; Valdes, A.; Cropet, C.; McCotter, O.Z.; Derado, G.; Couppié, P.; Chiller, T.; Nacher, M. Burden of HIV-associated histoplasmosis compared with tuberculosis in Latin America: A modelling study. Lancet Infect. Dis. 2018, 18, 1150-1159. [CrossRef]

12. Ashraf, N.; Kubat, R.C.; Poplin, V.; Adenis, A.A.; Denning, D.W.; Wright, L.; McCotter, O.; Schwartz, I.S.; Jackson, B.R.; Chiller, T.; et al. Re-drawing the Maps for Endemic Mycoses. Mycopathologia 2020, 185, 843-865. [CrossRef]

13. Deepe, G.S., Jr.; Dolin, R.; Blaser, M.J. 265-Histoplasma capsulatum (Histoplasmosis) A2 Douglas, and Bennett's Principles and Practice of Infectious Diseases, 8th ed.; Content Repository Only: Philadelphia, PA, USA, 2015; pp. 2949-2962.e1.

14. PAHO/WHO. Guidelines for Diagnosing and Managing Disseminated Histoplasmosis among People Living with HIV 2020. Available online: https:/iris.paho.org/bitstream/handle/10665.2/52304/9789275122495_eng. pdf?sequence $=1 \&$ isAllowed $=y$ (accessed on 1 April 2020).

15. Bartoletti, M.; Pascale, R.; Cricca, M.; Rinaldi, M.; Maccaro, A.; Bussini, L.; Fornaro, G.; Tonetti, T.; Pizzilli, G.; Francalanci, E.; et al. Epidemiology of invasive pulmonary aspergillosis among COVID-19 intubated patients: A prospective study. Clin. Infect. Dis. 2020, ciaa1065.

16. Gangneux, J.-P.; Reizine, F.; Guegan, H.; Pinceaux, K.; Le Balch, P.; Prat, E.; Pelletier, R.; Belaz, S.; Le Souhaitier, M.; Le Tulzo, Y.; et al. Is the COVID-19 Pandemic a Good Time to Include Aspergillus Molecular Detection to Categorize Aspergillosis in ICU Patients? A Monocentric Experience. J. Fungi 2020, 6, 105. [CrossRef]

17. Alanio, A.; Dellière, S.; Fodil, S.; Bretagne, S.; Mégarbane, B. Prevalence of putative invasive pulmonary aspergillosis in critically ill patients with COVID-19. Lancet Respir. Med. 2020, 8, e48-e49. [CrossRef]

18. Nasir, N.; Farooqi, J.; Mahmood, S.F.; Jabeen, K. COVID-19-associated pulmonary aspergillosis (CAPA) in patients admitted with severe COVID-19 pneumonia: An observational study from Pakistan. Mycoses 2020, 63, 766-770. [CrossRef]

19. Wang, J.; Yang, Q.; Zhang, P.; Sheng, J.; Zhou, J.; Qu, T. Clinical characteristics of invasive pulmonary aspergillosis in patients with COVID-19 in Zhejiang, China: A retrospective case series. Crit. Care 2020, 24, 1-4. [CrossRef]

20. Rutsaert, L.; Steinfort, N.; Van Hunsel, T.; Bomans, P.; Naesens, R.; Mertes, H.; Dits, H.; Van Regenmortel, N. COVID-19-associated invasive pulmonary aspergillosis. Ann. Intensiv. Care 2020, 10, 1-4. [CrossRef]

21. Van Arkel, A.L.E.; Rijpstra, T.A.; Belderbos, H.N.A.; van Wijngaarden, P.; Verweij, P.E.; Bentvelsen, R.G. COVID-19 Associated Pulmonary Aspergillosis. Am. J. Respir. Crit. Care Med. 2020, 202, 132-135. [PubMed]

22. Koehler, P.; Cornely, O.A.; Böttiger, B.W.; Dusse, F.; Eichenauer, D.A.; Fuchs, F.; Hallek, M.; Jung, N.; Klein, F.; Persigehl, T.; et al. COVID-19 associated pulmonary aspergillosis. Mycoses 2020, 63, 528-534. [CrossRef] [PubMed] 
23. Blaize, M.; Mayaux, J.; Nabet, C.; Lampros, A.; Marcelin, A.-G.; Thellier, M.; Piarroux, R.; Demoule, A.; Fekkar, A. Fatal Invasive Aspergillosis and Coronavirus Disease in an Immunocompetent Patient. Emerg. Infect. Dis. 2020, 26, 1636-1637. [CrossRef] [PubMed]

24. Lescure, F.-X.; Bouadma, L.; Nguyen, D.; Parisey, M.; Wicky, P.-H.; Behillil, S.; Gaymard, A.; Bouscambert-Duchamp, M.; Donati, F.; Le Hingrat, Q.; et al. Clinical and virological data of the first cases of COVID-19 in Europe: A case series. Lancet Infect. Dis. 2020, 20, 697-706. [CrossRef] [PubMed]

25. Antinori, S.; Rech, R.; Galimberti, L.; Castelli, A.; Angeli, E.; Fossali, T.; Bernasconi, D.; Covizzi, A.; Bonazzetti, C.; Torre, A.; et al. Invasive pulmonary aspergillosis complicating SARS-CoV-2 pneumonia: A diagnostic challenge. Travel Med. Infect. Dis. 2020, 2020, 101752. [CrossRef]

26. Meijer, E.F.J.; Dofferhoff, A.S.M.; Hoiting, O.; Buil, J.B.; Meis, J.F. Azole-Resistant COVID-19-Associated Pulmonary Aspergillosis in an Immunocompetent Host: A Case Report. J. Fungi 2020, 6, 79. [CrossRef]

27. Prattes, J.; Valentin, T.; Hoenigl, M.; Talakic, E.; Reisinger, A.C.; Eller, P. Invasive pulmonary aspergillosis complicating COVID-19 in the ICU-A case report. Med. Mycol. Case Rep. 2020. [CrossRef]

28. Fernandez, N.B.; Caceres, D.H.; Beer, K.D.; Irrazabal, C.; Delgado, G.; Farias, L.; Chiller, T.M.; Verweij, P.E.; Stecher, D. Ventilator-associated pneumonia involving Aspergillus flavus in a patient with coronavirus disease 2019 (COVID-19) from Argentina. Med. Mycol. Case Rep. 2020. [CrossRef]

29. Santana, M.F.; Pivoto, G.; Alexandre, M.A.A.; Baía-Da-Silva, D.C.; Borba, M.G.D.S.; Val, F.A.; Brito-Sousa, J.D.; Melo, G.C.; Monteiro, W.M.; Souza, J.V.B.; et al. Confirmed Invasive Pulmonary Aspergillosis and COVID-19: The value of postmortem findings to support antemortem management. Rev. Soc. Bras. Med. Trop. 2020, 53, e20200401. [CrossRef]

30. Sharma, A.; Hofmeyr, A.; Bansal, A.; Thakkar, D.; Lam, L.; Harrington, Z.; Bhonagiri, D. COVID-19 associated pulmonary aspergillosis (CAPA): An Australian case report. Med. Mycol. Case Rep. 2020, in press. [CrossRef]

31. Poignon, C.; Blaize, M.; Vezinet, C.; Lampros, A.; Monsel, A.; Fekkar, A. Invasive pulmonary fusariosis in an immunocompetent critically ill patient with severe COVID-19. Clin. Microbiol. Infect. 2020, in press. [CrossRef] [PubMed]

32. Salehi, M.; Ahmadikia, K.; Mahmoudi, S.; Kalantari, S.; Siahkali, S.J.; Izadi, A.; Kord, M.; Manshadi, S.A.D.; Seifi, A.; Ghiasvand, F.; et al. Oropharyngeal candidiasis in hospitalised COVID-19 patients from Iran: Species identification and antifungal susceptibility pattern. Mycoses 2020, 63, 771-778. [CrossRef] [PubMed]

33. Chowdhary, A.; Tarai, B.; Singh, A.; Sharma, A. Multidrug-Resistant Candida auris Infections in Critically Ill Coronavirus Disease Patients, India, April-July 2020. Emerg. Infect. Dis. 2020, 26, 2694-2696. [CrossRef] [PubMed]

34. Ventoulis, I.; Sarmourli, T.; Amoiridou, P.; Mantzana, P.; Exindari, M.; Gioula, G.; Vyzantiadis, T.-A. Bloodstream Infection by Saccharomyces cerevisiae in Two COVID-19 Patients after Receiving Supplementation of Saccharomyces in the ICU. J. Fungi 2020, 6, 98. [CrossRef]

35. Menon, A.A.; Berg, D.D.; Brea, E.J.; Deutsch, A.J.; Kidia, K.K.; Thurber, E.G.; Polsky, S.B.; Yeh, T.; Duskin, J.A.; Holliday, A.M.; et al. A Case of COVID-19 and Pneumocystis jirovecii Coinfection. Am. J. Respir. Crit. Care Med. 2020, 202, 136-138. [CrossRef]

36. Mang, S.; Kaddu-Mulindwa, D.; Metz, C.; Becker, A.; Seiler, F.; Smola, S.; Maßmann, A.; Becker, S.L.; Papan, C.; Bals, R.; et al. Pneumocystis Jirovecii Pneumonia and SARS-CoV-2 Co-Infection in newly diagnosed HIV-1 infection. Clin. Infect. Dis. 2020, ciaa906. [CrossRef]

37. Shah, A.S.; Heidari, A.; Civelli, V.F.; Sharma, R.; Clark, C.S.; Munoz, A.D.; Ragland, A.S.; Johnson, R.H. The Coincidence of 2 Epidemics, Coccidioidomycosis and SARS-CoV-2: A Case Report. J. Investig. Med. High. Impact Case Rep. 2020, 8, 1-4. [CrossRef]

38. Hughes, S.; Troise, O.; Donaldson, H.; Mughal, N.; Moore, L. Bacterial and fungal coinfection among hospitalized patients with COVID-19: A retrospective cohort study in a UK secondary-care setting. Clin. Microbiol. Infect. 2020, 26, 1395-1399. [CrossRef]

39. Zhu, X.; Ge, Y.; Wu, T.; Zhao, K.; Chen, Y.; Wu, B.; Zhu, F.; Zhu, B.; Cui, L. Co-infection with respiratory pathogens among COVID-2019 cases. Virus Res. 2020, 285, 198005. [CrossRef]

40. Chen, N.; Zhou, M.; Dong, X.; Qu, J.; Gong, F.; Han, Y.; Qiu, Y.; Wang, J.; Liu, Y.; Wei, Y.; et al. Epidemiological and clinical characteristics of 99 cases of 2019 novel coronavirus pneumonia in Wuhan, China: A descriptive study. Lancet 2020, 395, 507-513. [CrossRef] 
41. Yang, X.; Yu, Y.; Xu, J.; Shu, H.; Xia, J.; Liu, H.; Wu, Y.; Zhang, L.; Yu, Z.; Fang, M.; et al. Clinical course and outcomes of critically ill patients with SARS-CoV-2 pneumonia in Wuhan, China: A single-centered, retrospective, observational study. Lancet Respir. Med. 2020, 8, 475-481. [CrossRef]

42. Du, Y.; Tu, L.; Zhu, P.; Mu, M.; Wang, R.; Yang, P.; Wang, X.; Hu, C.; Ping, R.; Hu, P.; et al. Clinical Features of 85 Fatal Cases of COVID-19 from Wuhan. A Retrospective Observational Study. Am. J. Respir. Crit. Care Med. 2020, 201, 1372-1379. [CrossRef]

43. Gangneux, J.-P.; Bougnoux, M.-E.; Dannaoui, E.; Cornet, M.; Zahar, J. Invasive fungal diseases during COVID-19: We should be prepared. J. Mycol. Méd. 2020, 30, 100971. [CrossRef] [PubMed]

44. Baum, A.; Kaboli, P.J.; Schwartz, M.D. Reduced In-Person and Increased Telehealth Outpatient Visits During the COVID-19 Pandemic. Ann. Intern. Med. 2020. [CrossRef] [PubMed]

45. Loupy, A.; Aubert, O.; Reese, P.P.; Bastien, O.; Bayer, F.; Jacquelinet, C. Organ procurement and transplantation during the COVID-19 pandemic. Lancet 2020, 395, e95-e96. [CrossRef]

46. Siow, M.Y.; Walker, J.T.; Britt, E.; Kozy, J.P.; Zanzucchi, A.; Girard, P.J.; Schwartz, A.K.; Kent, W.T. What Was the Change in Telehealth Usage and Proportion of No-show Visits for an Orthopaedic Trauma Clinic During the COVID-19 Pandemic? Clin. Orthop. Relat. Res. 2020, 478, 2257-2263. [CrossRef]

47. Geri, P.; Salton, F.; Zuccatosta, L.; Tamburrini, M.; Biolo, M.; Busca, A.; Santagiuliana, M.; Zuccon, U.; Confalonieri, P.; Ruaro, B.; et al. Limited role for bronchoalveolar lavage to exclude Covid-19 after negative upper respiratory tract swabs: A multicenter study. Eur. Respir. J. 2020, 56, 2001733. [CrossRef]

48. Wahidi, M.M.; Lamb, C.; Murgu, S.; Musani, A.; Shojaee, S.; Sachdeva, A.; Maldonado, F.; Mahmood, K.; Kinsey, M.; Sethi, S.; et al. American Association for Bronchology and Interventional Pulmonology (AABIP) Statement on the Use of Bronchoscopy and Respiratory Specimen Collection in Patients with Suspected or Confirmed COVID-19 Infection. J. Bronc. Interv. Pulmonol. 2020, 27, e52-e54. [CrossRef]

49. Lai, C.-C.; Wang, C.-Y.; Hsueh, P.-R. Co-infections among patients with COVID-19: The need for combination therapy with non-anti-SARS-CoV-2 agents? J. Microbiol. Immunol. Infect. 2020, 53, 505-512. [CrossRef]

50. Clancy, C.J.; Nguyen, M.H. COVID-19, superinfections and antimicrobial development: What can we expect? Clin. Infect. Dis. 2020, ciaa524. [CrossRef]

51. Rawson, T.M.; Moore, L.S.P.; Zhu, N.; Ranganathan, N.; Skolimowska, K.; Gilchrist, M.; Satta, G.; Cooke, G.; Holmes, A. Bacterial and Fungal Coinfection in Individuals With Coronavirus: A Rapid Review To Support COVID-19 Antimicrobial Prescribing. Clin. Infect. Dis. 2020, ciaa530. [CrossRef] [PubMed]

52. García, L.F. Immune Response, Inflammation, and the Clinical Spectrum of COVID-19. Front. Immunol. 2020, 11, 1441. [CrossRef]

53. Chen, G.; Wu, D.; Guo, W.; Cao, Y.; Huang, D.; Wang, H.; Wang, T.; Zhang, X.; Chen, H.; Yu, H.; et al. Clinical and immunological features of severe and moderate coronavirus disease 2019. J. Clin. Investig. 2020, 130, 2620-2629. [CrossRef]

54. Davies, M.-A. HIV and risk of COVID-19 death: A population cohort study from the Western Cape Province, South Africa. medSouth Afrxivca 2020. Available online: https://www.medrxiv.org/content/10.1101/2020.07.02. 20145185v2 (accessed on 27 October 2020). [CrossRef]

55. Suwanwongse, K.; Shabarek, N. Clinical features and outcome of HIV/SARS-CoV-2 coinfected patients in The Bronx, New York city. J. Med. Virol. 2020, 92, 2387-2389. [CrossRef] [PubMed]

56. Gervasoni, C.; Meraviglia, P.; Riva, A.; Giacomelli, A.; Oreni, L.; Minisci, D.; Atzori, C.; Ridolfo, A.L.; Cattaneo, D. Clinical features and outcomes of HIV patients with coronavirus disease 2019. Clin. Infect. Dis. 2020, ciaa579. [CrossRef] [PubMed]

57. Blanco, J.L.; Ambrosioni, J.; Garcia, F.; Martínez, E.; Soriano, A.; Mallolas, J.; Miro, J.M. COVID-19 in patients with HIV: Clinical case series. Lancet HIV 2020, 7, e314-e316. [CrossRef]

58. Childs, K.; Post, F.A.; Norcross, C.; Ottaway, Z.; Hamlyn, E.; Quinn, K.; Juniper, T.; Taylor, C. Hospitalized patients with COVID-19 and HIV: A case series. Clin. Infect. Dis. 2020, 71, 2021-2022. [CrossRef]

59. Woloshin, S.; Patel, N.; Kesselheim, A.S. False Negative Tests for SARS-CoV-2 Infection-Challenges and Implications. N. Engl. J. Med. 2020, 383, e38. [CrossRef]

60. Wang, W.; Xu, Y.; Gao, R.; Lu, R.; Han, K.; Wu, G.; Tan, W. Detection of SARS-CoV-2 in Different Types of Clinical Specimens. JAMA 2020, 323, 1842-1844. [CrossRef]

61. Bwire, G.M.; Majigo, M.V.; Njiro, B.J.; Mawazo, A. Detection profile of SARS-CoV-2 using RT-PCR in different types of clinical specimens: A systematic review and meta-analysis. J. Med. Virol. 2020, 1-7. [CrossRef] [PubMed] 
62. Yang, Y.; Yang, M.; Shen, C.; Wang, F.; Yuan, J.; Li, J.; Zhang, M.; Wang, Z.; Xing, L.; Wei, J.; et al. Evaluating the accuracy of different respiratory specimens in the laboratory diagnosis and monitoring the viral shedding of 2019-nCoV infections. medRxiv 2020, 2020. Available online: https://www.medrxiv.org/content/10.1101/ 2020.02.11.20021493v2 (accessed on 27 October 2020). [CrossRef]

63. CDC. Interim Infection Prevention and Control Recommendations for Healthcare Personnel During the Coronavirus Disease 2019 (COVID-19) Pandemic 2020. Available online: https://www.cdc.gov/coronavirus/ 2019-ncov/hcp/infection-control-recommendations.html (accessed on 4 November 2020).

64. Wheat, L.J.; Freifeld, A.G.; Kleiman, M.B.; Baddley, J.W.; McKinsey, D.S.; Loyd, J.E.; Kauffman, C.A. Clinical Practice Guidelines for the Management of Patients with Histoplasmosis: 2007 Update by the Infectious Diseases Society of America. Clin. Infect. Dis. 2007, 45, 807-825. [CrossRef] [PubMed]

Publisher's Note: MDPI stays neutral with regard to jurisdictional claims in published maps and institutional affiliations.

(C) 2020 by the authors. Licensee MDPI, Basel, Switzerland. This article is an open access article distributed under the terms and conditions of the Creative Commons Attribution (CC BY) license (http://creativecommons.org/licenses/by/4.0/). 